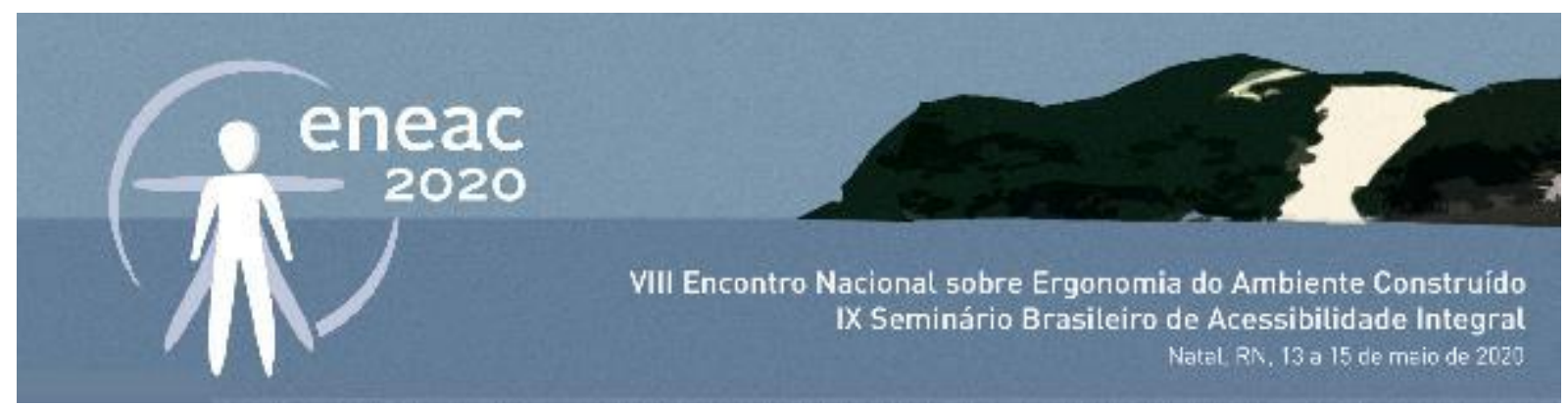

\title{
Ergonomia, Neurociência e Acessibilidade
}

\section{Neuroergonomics, Neuroscience and Accesibility}

\author{
VILMA VILLAROUCO \\ Doutora em Engenharia de Produção. PPGAUD/UFC, PPGDesign e PPErgo/UFPE, \\ vvillarouco@gmail.com
}

PAULO NASCIMENTO

Mestre em Educação, Instituto Le Santè, Fortaleza, pauloneurofeedback@gmail.com

\section{RESUMO}

A conjugação da neurociência à ergonomia e ao design (neuroergonomia e neurodesign) abre a possibilidade de avaliação das sensações e emoções que são experienciadas pelas pessoas ao testar um produto, ver-se diante de novos ambientes internos ou urbanos ou mesmo em situações cotidianas de vivência ambiental. É neste contexto que a pesquisa em desenvolvimento explanada nesta Mesa Redonda do ENEAC 2020 trabalha a adoção da eletroencefalografia (EEG) e biomarcadores de frequência cardíaca para avaliação de navegação de pessoas com cegueira em rotas urbanas, utilizando-se tanto a informação verbalizada quanto os mapas táteis para definição dos trajetos. Adota o princípio de que a captação e análise das ativações de áreas cerebrais, por meio da utilização do EEG permite entender sensações de pessoas com cegueira, ao enfrentar o desafio de caminhar em espaços urbanos por caminhos pré-definidos. Estando cada função orgânica e cada função externa vinculadas as sensações e percepções ligadas diretamente com uma área encefálica específica utiliza-se os conceitos da neuroanatomia funcional para caracterizar as áreas e suas funções. Na condução desta pesquisa os resultados das gravações de EEG tem identificado ativações de áreas cerebrais por ondas que indicam reações de tranquilidade, atenção e também de ansiedade, perfeitamente associáveis ao momentos e situações vivenciadas. A apliçção da neurociência nos estudos do ambiente construído e suas diversas vertentes aponta para um caminho rico em possibilidades, coloca luzes sobre o entendimento e melhor esclarecimento da percepção humana sobre as configurações dos espaços, suas características e as variáveis diversas nele envolvidas, a partir da compreensão das reações encefálicas.

PALAVRAS-CHAVE: neuroergonomia, acessibilidade urbana, rotas com mapas táteis. 